NBER WORKING PAPER SERIES

\title{
CHANGES OVER TIME IN UNION \\ RELATIVE WAGE EFFECTS IN GREAT \\ BRITAIN AND THE UNITED STATES
}

David G. Blanchflower

Working Paper 6100
NATIONAL BUREAU OF ECONOMIC RESEARCH 1050 Massachusetts Avenue
Cambridge, MA 02138
July 1997

I thank the US Department of Labor for funding under purchase order No. 284044 from the Bureau of International Labor Affairs. Points of view or opinions stated in this document do not necessarily represent the official position or policy or the US Department of Labor or the National Bureau of Economic Research. This paper is part of NBER's research program in Labor Studies.

(C) 1997 by David G. Blanchflower. All rights reserved. Short sections of text, not to exceed two paragraphs, may be quoted without explicit permission provided that full credit, including $\odot$ notice, is given to the source. 
Changes Over Time in Union Relative Wage

Effects in Great Britain and the United States

David G. Blanchflower

NBER Working Paper No. 6100

July 1997

Labor Studies

\begin{abstract}
This paper uses broadly comparable micro data at the level of the individual to examine the extent to which union relative wage effects vary across groups and through time. The main findings may be summarized as follows. a) The union wage gap averages $15 \%$ in the US and $10 \%$ in Great Britain. b) The gap is positively correlated with the (lagged) unemployment rate, and appears to be untrended in both countries. Union wages are sticky. c) The size of the wage gap varies across groups. In both the US and Great Britain the differential is relatively high in the private sector, in non-manufacturing, for manuals, the young and the least educated. d) In the US there are no differences by race or gender in the size of the differential. In Great Britain it is higher both for women and non-whites. The fact that the differential has remained more or less constant in both Great Britain and the US is a puzzle, particularly given the rapid declines in union membership in both countries. The evidence does not appear to be consistent with the widely held view that union power has been emasculated.
\end{abstract}

David G. Blanchflower

Department of Economics

6106 Rockefeller Hall

Dartmouth College

Hanover, NH 03755

and NBER

david.g.blanchflower@dartmouth.edu 
"As all economics data files have weaknesses - measurement error, unmeasured variables, sample survey quirks - and all model specifications are questionable, contaminated by data mining, any 'finding' ought to be replicated on several data sets and under 'plausible' model specifications before one accepts it as valid. Replication with additional data and specifications contrasts sharply with the practice of econometricians who postulate a 'true' model, use maximum likelihood search procedures to extract its parameters from data, and stop, as if technical prowess rather than robustness of results was the key to credibility. In fact, as all practitioners know, any single piece of complex econometric analysis rarely convinces anyone, for the more sophisticated the econometrics, the greater the danger the results derive from the model than from the world. In economics it is the accumulation of disparate lines of evidence, not the elegance of the statistical technology for a single estimator, that is compelling."

Richard Freeman, Labor Markets in Action, Harvard University Press, 1989, p.xi)

It is a well known result that unions raise wages, holding constant characteristics of the individual as well as of the industry, area and workplace. Of particular interest is by how much does this vary by country, across groups and through time? In this paper these questions are examined using broadly comparable data for Great Britain and the United States. I first started work on this issue as a graduate student at Queen Mary College in 1983 after being persuaded to do so by Bernard Corry. He told me that a) this was a great topic and b) there was nowhere else as wonderful as QMC to do this work. Probably because I was young and inexperienced at the time I believed him on both counts! I eventually wrote my $\mathrm{Ph} . \mathrm{D}$. thesis ${ }^{1}$ on the issue, with lots of input from both Maurice and Bernard. Over the subsequent dozen years or so I have revisited the question several times, both on my own and with a number of co-authors ${ }^{2}$. Hence it seemed like a pretty good topic to return to for their Festschrift. Having spent the last eight years in the United States it seemed to make sense to compare what unions do on the wage front in the two countries. So here goes with a few thoughts from the other side of the pond.

What is estimated in this literature is the difference between ceteris paribus earnings of union and non-union workers. That is, how much would wages change if an individual changed from non-union to union status, holding constant their individual and workplace characteristics. 
The vast majority of work estimating the effects of unions on relative wages has been based on US data. The definitive works in this area are by Lewis, $(1963,1986)$. The first of his two books measured the effects of unions using relatively aggregated data at the industry level backed up by case study evidence. In the 1986 volume Lewis examined approximately 200 studies that had used micro-data to estimate the effect of unions. He concluded that it was not possible to use "macro" data to estimate the union wage gap and that methodologically estimating an Ordinary Least Squares (OLS) equation with wages on the left, union status on the right with a group of controls, was probably the best way to estimate the size of the effect. Panel estimates had problems of misclassification and measurement error while simultaneous equation methods suffered from poor identification due to a lack of suitable instruments. Lewis (1986) argued that estimates obtained using OLS were likely to be upper bounds of the true effect because of the omission of controls correlated with the union status variable.

After an examination of the results of the US studies, many of which he re-estimated himself, Lewis concluded that during the period 1967-1979 the US the mean wage gap was approximately $15 \%$. He found that the gap was greater for blacks than whites; in services than in manufacturing; for construction than for other non-manufacturing; for blue-collar workers than for white-collar; for private than for public sector workers. The estimates for men and women were approximately the same. The wage gap falls as years of schooling, establishment or firm size and industry unemployment rates rise. For age, years of experience and years of seniority the gap at first falls and then rises. The robustness of Lewis's results were broadly confirmed by Jarrell and Stanley (1990) using meta-analysis, although their mean estimate of the wage gap for the period was a little lower than that obtained by Lewis.

Over the past couple of decades there has been a growing body of literature estimating the size of the union wage gap outside the US. There are a few studies for Canada which suggest that the union wage gap is in the range $10 \%-15 \%$. This estimate appears to have remained fairly constant over time 3 . In Australia the estimated range is between $7 \%$ and $17 \%$ with most estimates at the lower end of the range ${ }^{4}$. Moll (1993) obtained estimates for South Africa in 1985 of $24 \%$ 
for black blue-collar workers (19\% for black men and $31 \%$ for black women) and $13 \%$ for whites in 1985. For South Korea, Park (1991) obtained estimates of $4.2 \%$ men and 5\% for women. Wagner (1991) found significant positive union effects for blue collar workers in Germany while Schmidt (1995) found small but significant wage differentials of under 6\%. Neither Schmidt (1995) nor Schmidt and Zimmermann (1991) were able to find evidence of significant union wage gaps for men 5 .

For Great Britain there have been approximately twenty studies some based on establishment data ${ }^{6}$, and some on individual data ${ }^{7}$. The consensus seems to be (see Booth, 1995 for a discussion) that the mean union wage gap is approximately $10 \%$. Despite the rapid decline in union density experienced in the UK since 1979, there is some evidence to suggest that the gap has remained roughly constant since 1970 (see Blanchflower, 1991 and Stewart 1995), the year for which the earliest estimate is available (Shah, 1984), although there is some dispute on this question (see Lanot and Walker, 1997). The disaggregated pattern of results reported by Lewis (1986) for the US appear to be broadly repeated for the UK. The main exception is that the wage gap in the UK appears to be larger for females than it is for males (see Blanchflower, 1991 and Main, 1996). Some care has to be taken in comparing the estimates from the British studies because they often relate to quite disparate groups of workers - usually manuals (Stewart, 1994), sometimes male manuals only (e.g. Shah, 1984) and occasionally full-time male manuals (Stewart, 1983). Moreover, all of the estimates obtained from establishment level data (from the Workplace Industrial Relations Survey series) exclude workers employed at small workplaces (Blanchflower, 1984 and Stewart, 1987). As we show below there is considerable variation in the differential across groups (e.g. by establishment size, occupation, industry sector etc.) which means that sample exclusions will potentially result in biases in the 'overall' result.

In what follows a series of estimates for the union wage gap in the 1980s and 1990s are presented for both Great Britain and the US. Comparable micro-data files at the level of the individual are used to estimate log hourly earnings equations which contain similar groups of control variables for the two countries. The British data files are a lot smaller than those for the 
US, which necessitates making use of data from a number of different sources. Clearly one would wish to also examine the extent to which unions are able to influence the total compensation package including fringe benefits. Unfortunately relatively little is known about the extent to which unions are able to influence fringe benefits, primarily because of a lack of suitable data. Such literature as does exist - virtually all of which is for the USA -- suggests that these effects are large (see Freeman and Medoff, 1984). None of our data files contain adequate information that would allow us to examine this issue.

Before moving to estimating union wage gaps it is appropriate to place these results in the wider context of the changes in the labour market experience of the two countries over the last couple of decades.

There are five basic facts to be kept in mind.

1. Unemployment was generally higher in the US than it was in the UK from 1965-1980. The picture reversed itself in the later period, 1980-1995 (Figure 1).

2. Both employment and the size of the labor force increased rapidly over the period 1980-1994 in the US as is illustrated below. The UK experienced only small growth on both of these dimensions over this period. Consequently, the gap in the employment/population ratios between the two countries widened over the period.

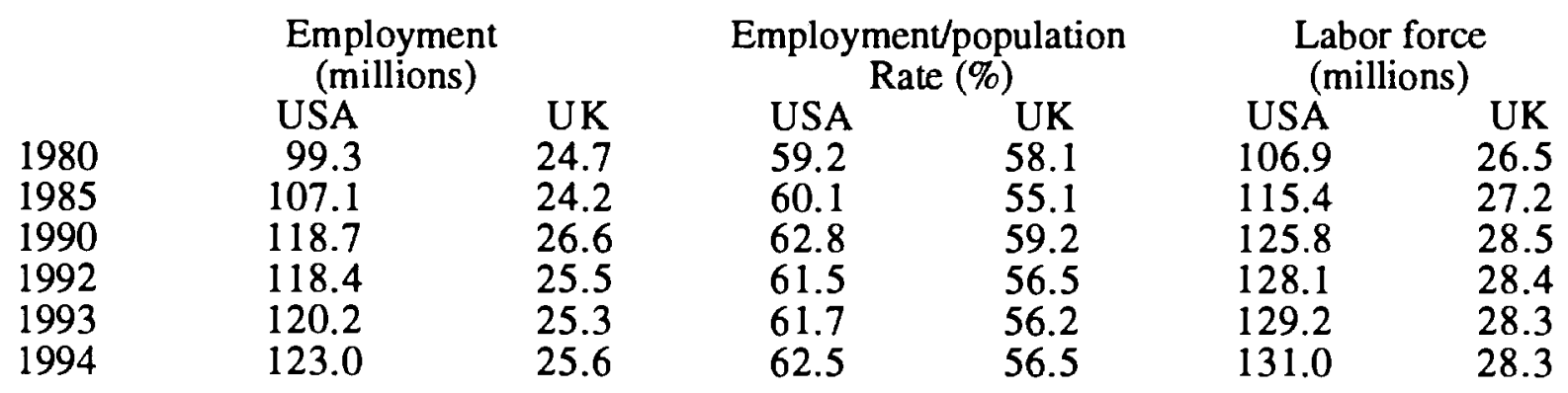

Source: Statistical Abstract of the US. 1996-7.

3. There was substantial growth in earnings inequality in the 1970s and 1980 s in the US. Earnings inequality declined in the UK in the 1970s but increased in the 1980s. This is illustrated in Figures 2a and 2b which are taken from Katz et al (1995) and which plot the time series of 
overall wage inequality of men and women as measured by the log hourly wage differential between the ninetieth and the tenth percentiles of the wage distribution. There is much less evidence of rising wage inequality in other countries over the period (see the various papers in Freeman and Katz, 1995).

4. Real wage growth has been much higher in the UK than in the US, and especially so at the low end of the distribution. Figures $3 a$ and $3 b$, which are also taken from Katz et al (1995) illustrate this by plotting the real earnings of the ninetieth, fiftieth and tenth percentiles of the wage distributions for men in the two countries. More precisely the figure displays the log ratio of each group's real earnings in each year relative to the group's real earnings in 1979 (the base year). The two panels show fairly similar increases in the 90-10 differential in the 1980s in Britain and the US but indicate that these increases implied a 0.12 decline in log real hourly earnings from 1979 to 1989 at the tenth percentile in the US wage distribution and a 0.12 increase in real log earnings at the same point of the British distribution. The figure indicates that only in the US was rising wage inequality in the 1980s accompanied by declining real wages for low wage males. Even the median US male employee experienced a modest decline in log real hourly earnings from 19791989; his UK counterpart experienced a 0.24 increase in log real hourly earnings over the same period.

5. Union density rates declined steadily in the US from $1970^{8}$. In the UK density increased in the 1970s and then declined dramatically thereafter (Figure 4). The decline in density was also pronounced in Japan and Austria. Some countries experienced increases in density over the period (e.g. Denmark, Finland and Sweden). For a discussion see Blanchflower and Freeman 1992 and Blanchflower, 1996.

In the next section data from the 1983-1995 Outgoing Rotation Group files of the Current Population Survey are used to obtain estimates of the impact of trade unions on hourly earnings for the US. Separate estimates are obtained from each of these cross-sections which allow us to examine movements in the union wage gap over time. In the following section cross-section data from various individual level datasets for Great Britain are used to perform a similar exercise for 
Great Britain. It is found that the level of the union wage gap is untrended over time, but positively correlated with the unemployment rate in both countries.

\section{Union wage differentials in the USA}

In Table 1 the results of estimating a log hourly earnings equations for 1983 using data from the Outgoing Rotation Group files of the CPS are reported. Control variables are a union status dummy plus age and its square, a gender dummy, years of schooling, a part-time dummy, two race dummies, three sector of work dummies, two self-employment dummies plus fifty state and fifty industry dummies. In total there are just over 170,000 observations. The dependent variable is defined as the log of usual hourly earnings for hourly paid workers and for the remainder as the log of usual weekly earnings/usual weekly hours ${ }^{9}$. The overall union wage effect is estimated at $15.5 \%$ (antilog of .1445 from column 1 minus one because the dependent variable is in logarithms). Columns 2-8 of the Table report disaggregated estimates. The union wage gap is higher in the private sector (16.9\%) than it is in the public sector (8.8\%). Results by gender and race are all close to $15 \%$.

Table 2 reports the results of estimating a very similar specification to that in Table 1, using the same data source, but now for 1993. The main exception is that years of schooling are replaced by 15 schooling dummies to distinguish highest level of schooling attended. This change is necessary because of changes in the CPS survey design. Results are very similar to those for 1983 discussed above. The union wage differential remains unchanged at $15.5 \%$ - remarkably the estimates in columns 1 of both Tables 1 and 2 vary only at the fourth place of decimals. Once again there is little difference by gender or race. However, the differential in the public sector in 1993 is slightly higher than it was in 1983 (8.8\% and $11.8 \%$ respectively). Overall the wage gap in the US is very close to that estimated in Lewis (1986), despite both a dramatic decline in density along with a large increase in earnings inequality that has occurred since then.

Is the high differential in the US an artifact of sample selectivity? In Blanchflower and Freeman (1992) it was argued that this is not the correct way to interpret the data and this is still my view. The reasons given, which are still relevant, were as follows. 
1. Evidence within the US tends to reject the notion that union wage effects are large when union density is small. Union wage differentials tend to be greater the greater the extent of unionization in the sector (see Lewis, 1986 and Freeman and Medoff, 1984), presumably because this gives unions greater bargaining power.

2. If selectivity were the major cause of the estimated large effects of unionism on wages in the US, similar differences in other market outcomes should be expected, which is not found.

3. Third, the fact that employers as well as workers affect union density makes the direction of the selectivity effect uncertain. One might well argue that selectivity operates to bias down union wage effects in the US as employers fight hardest against unions that have the most potential for raising wages and accept unions when they have the least potential.

4. Massive employer opposition to unions in the US but not elsewhere is consistent with the greater demand by unions for higher wages in the US than in other countries.

All of this does not deny the possibility that our estimates may be contaminated by the reverse effects of density on wage differentials, rather it is probable that this potential contamination is unlikely to reverse the finding that union wage differentials are relatively high for similar workers in the US.

A number of earlier studies have examined the extent to which the mean union wage gap has varied over time in the US. As discussed earlier, Lewis (1986) reported an average union wage gap for the period $1967-1979$ of $15 \%$. He further reported on time series movements in the differential, by taking the mean estimate by year from each of the 150 studies he surveyed. Subsequent work by Linneman, Wachter and Carter (1990), extending earlier work on the subject presented in Linneman and Wachter (1986), used the CPS to estimate wage gaps for full-time nonagricultural workers for the years from 1973-1986. The two sets of results are plotted in Figure 5. In addition the Figure also plots new estimates for the intervening years between 1983 and 1995 that were obtained from estimating eleven further earnings equations of the form presented in column 1 of both Tables 1 and 2. The data are drawn from the Outgoing Rotation Group files of the CPS for each year in turn ${ }^{10}$. In total there are two and a quarter million observations, with an 
average of around 170,000 observations per year. The union dummy is always highly significant with t-statistics everywhere greater than 40 . The full results are below. The union wage gap is calculated as the natural antilog of the union coefficient minus one.

$\begin{array}{lccc}\text { Year } & \text { Union coefficient } & \text { Union wage gap } & \text { Number of observations } \\ 1983 & .1445 & 15.6 & 173,404 \\ 1984 & .1519 & 16.4 & 172,970 \\ 1985 & .1428 & 15.4 & 179,710 \\ 1986 & .1435 & 15.4 & 178,969 \\ 1987 & .1366 & 14.6 & 180,165 \\ 1988 & .1360 & 14.6 & 172,813 \\ 1989 & .1375 & 14.7 & 176,158 \\ 1990 & .1300 & 13.9 & 184,731 \\ 1991 & .1222 & 13.0 & 179,261 \\ 1992 & .1330 & 14.2 & 176,492 \\ 1993 & .1440 & 15.5 & 171,439 \\ 1994 & .1470 & 15.8 & 149,819 \\ 1995 & .1390 & 14.9 & 152,274 \\ & & 14.9 & 172,939 \\ \text { Average } & & & 2,248,205\end{array}$

Where the three series in Figure 5 overlap, there is considerable agreement on both the size and movements in the mean wage gap -- the estimates are never more than one percentage point apart. The average union wage premium over the period 1967-1993 is estimated at approximately $15 \%$. There is a clear cyclical pattern: there are obvious peaks in 1977, 1983/4 and 1993 and troughs in 1979 and 1991 . These cyclical patterns approximate fairly closely movements in the aggregate unemployment rate, which is also plotted in Figure 5. Unemployment was low in 1979 and high in 1983 and 1992, for example. When unemployment is low the union wage premia appears to be low and vice versa. Despite some evidence of cyclicality the dominant impression from the figure is the relative constancy of the differential over this long time period, even though the labor market has, along other dimensions, experienced so much turbulence over same time period.

A series of time series equations were estimated to explain movements in the union differential over time. This is simply meant to be illustrative: no attempt is made to correct for serial correlation or to estimate any fully specified model. Where there was more than one estimated differential for a single year I simply took the average. It appears that a) unemployment lagged one period enters positively and significantly; 
b) contemporaneous unemployment is insignificantly different from zero;

c) there is statistically weak evidence of a significant time trend in the data

d) the lagged dependent variable is everywhere insignificant.

e) the CPI (and lags) were also always insignificant.

Hence we conclude that the union wage differential is untrended but positively correlated with the unemployment rate and uncorrelated with the inflation rate ${ }^{11}$. This presumably arises because union wages are less responsive to changes in the unemployment rate than are non-union wages confirming wage curve results in Blanchflower and Oswald (1994). The unemployment elasticity of pay is higher in the non-union sector than it is in the union sector (Table 4.19, p.159).

An obvious question to ask is why has union membership and union employment been in decline given the relative constancy of the union wage premium? As was noted above, the level of the differential -- at around $15 \%$-- is still very high by international standards. The United States decides union membership through an adversarial electoral process at plant level which has evolved into a system where management has a greater say in unionization outcomes than it does in other countries. The benefits to employers in removing unions from the workplace often outweigh the costs of doing so. The costs to unions in organizing recruitment drives is high ${ }^{12}$. Bender (1996) has argued that the loss of economies of scale in union organizing is an important factor in explaining union decline. It is much harder for employers in other countries to get rid of unions than it is in the US. Even in the UK there are only a very few examples of union de-recognition. Employers are unable to hide from a union; they have no place to go.

The decline in US unionism seems to have been driven by employer opposition, fueled by more competitive product markets, increased international trade and a favorable legal environment, which has meant that there have been smaller economic rents to be shared with workers than was true in the past ${ }^{13}$. It is unlikely to be a coincidence that the generally lower union-nonunion wage differentials that operated in the late $80 \mathrm{~s}$ and $90 \mathrm{~s}$, as compared with those that existed in the $70 \mathrm{~s}$, were associated with a marked slowing in the rate of decline in US union density (see Figure 4). 
Similarly the 1970 s, which were a period of high and growing union wage differentials, saw rapid declines in private sector union density.

Linneman, Wachter and Carter (1990) have gone even further and suggested that the evidence of a relatively constant aggregate union wage premium is a "statistical artifact" (1990, p.51). High premium industries, they show, have been increasing their union wage premia and losing employment shares and hence membership of trade unions. Union wage premia in private services, they argue, have held constant or fallen. They argue that even though unions have been hurt by exogenous factors which have created shifts in demand from goods to service-producing industries, unions have been hurt most by the rising wage premia. Supporting evidence for this view is presented by Freeman (1986) who found a positive correlation between the union wage gap and a proxy for managerial opposition to unions -- the number of unfair labour practices per worker in NLRB elections. Farber (1990) also concludes that the decline is principally a result of increased employer opposition to unions along with lower demand for union services by workers.

\section{Union wage differentials in Great Britain}

There is no single long time-series of large cross-sections for Great Britain that contain data on both wages and union status. The Labour Force surveys (LFS), which are large and contain a long time-series of cross-sections has only recently started asking questions on wages. Although there are quite a number of British individual level micro-data files, only occasionally do they contain data on these two crucial variables. We make use of data from the 1983 General Household Survey (GHS), the 1993 and 1994 Labour Force Surveys, the British Social Attitudes Survey (BSA), 1983-1994 and the British Household Panel Study (BHPS), 1991-1993. Where possible we try to replicate results by year on more than one data file. The number of observations is everywhere much less than was available for the US, ranging from a high of around 8,000 per year in the GHS and LFS to a few hundred observations a year for the BSA surveys.

Table 4 reports the results of estimating a log hourly earnings equation for Great Britain using data from the General Household Survey for 1983. This is the same source used by Green (1988). When missing values are deleted data are available on only around 8,000 individuals. A 
group of control variables similar to those used for the US (age and its square, gender, race, highest qualification, size of establishment, region and industry and month of interview) were included. Consistent with earlier studies which found estimates of around $10 \%$, the estimated differential is approximately $11.2 \%$. Results in the public and private sectors are very similar. The differential for females is higher than for males ( $12.5 \%$ and $8.6 \%$ respectively) confirming earlier work by Blanchflower (1991) and Main (1996).

Table 5 performs a similar exercise but now for $1993 / 4$ using pooled data from the 1993 and 1994 Labour Force Surveys. (Union membership data is not available in any subsequent GHS or in earlier LFS's). Even though these surveys are large, only the Outgoing Rotation groups -- a fifth of the sample -- are asked to report wages, which means a total sample size of just over 16,000 when the two years are pooled. The purpose behind pooling is to raise sample size. The female differential is now more than double that of males ( $12.5 \%$ and $6.0 \%$ respectively). Separate estimates are rported for the two years. The picture is very similar to that of the US, where despite large declines in density, the union wage differential remained largely unchanged between 1983 and 1993/4. Our estimate of the overall wage gap is little changed, and not significantly different, from the 1983 result; it is now estimated at $9.8 \%$.

The evidence of a relatively constant differential over time in the UK is consistent with earlier work presented in Blanchflower (1991), where union wage effects were estimated using data from the 1983-1987 and 1989 British Social Attitude Surveys. I obtained estimates of 10\% with no significant variation over the years ${ }^{14}$. In Table 6 the equations reported in the earlier paper are re-estimated adding the 1990, 1991, 1992 and 1994 surveys. Results are reported for both annual earnings and for hourly earnings. The reason for the shorter time run when hourly earnings are used arises because of the lack of suitable hours data in the earliest years. The small differences from the earlier results arise from variation in the group of right hand side variables. The finding of the constancy of the differential at around $10 \%$ is unchanged. There is no significant variation across the years. 
Table 7 provides further validation using data of the constancy result using the first three sweeps of the British Household Panel Study for the years 1991-3. The first column pools all three waves of the survey. A union wage gap of $11.1 \%$ is estimated. The next three columns report results separately by year. Estimates vary from $9.3 \%$ in 1991 to $12.7 \%$ in 1193 . Interaction terms between the year dummies and the union status dummy were insignificantly different from zero suggesting no significant variation in the differential over time. Differentials for women are more than double those of men, confirming results reported above. Finally, in columns 8 through eleven the first panel estimates of the union wage gap for Great Britain are reported. In this specification the three years are pooled and a full set of people fixed effects. As was found in the US literature panel estimates are generally lower than the OLS estimates, principally because of problems of misclassification and measurement error (see Freeman, 1984). Now the wage gap has fallen to $3.8 \%$, with only a small difference between the findings for men and women. As far as I am aware this is the first panel estimate of the wage gap has been reported for Great Britain. It would be interesting to trace how this estimate moves through time as more sweeps of this survey become available.

The table below summarizes the findings of the extent of variation in the wage gap in Great Britain from 1983-1994. Other estimates are available but they are for specific sub-groups (e.g. males, manuals, or more usually, male manuals); we report here only estimates using individual level data for all groups of employees. The average is $10.7 \%$.

Hourly earnings union wage premia.

$\begin{array}{lrlrrr}\text { Year } & B S A & \text { GHS } & \text { LFS } & \text { BHPS } & \begin{array}{c}\text { Average } \\ 11.2\end{array} \\ 1983 & & 11.2 & & & 1.2 \\ 1986 & 1.2^{*} & & & & 17.1 \\ 1987 & 17.1 & & & & 11.6 \\ 1989 & 11.6 & & & & 11.3 \\ 1990 & 11.3 & & & 8.7 & 8.1 \\ 1991 & 9.1 & & & 12.5 & 12.5 \\ 1992 & 7.2 & & & 12.7 & 12.8 \\ 1993 & 16.8 & & 9.0 & & 12.5 \\ 1994 & 14.4 & & 10.5 & & 10.7 \\ \text { Average } & & & & & \end{array}$

Note: ${ }^{*}=$ not significantly different from zero. 
Figure 6 plots the average for the years from the final column against the unemployment rate. As was found for the US, the wage gap appears to vary positively with the unemployment rate, although the evidence is considerably weaker given the small number of time points. Table 8 reports a number of time series regressions to examine the relationship between the wage gap and the unemployment rate. Column 1 reports a very poor equation for Great Britain alone. Because of the small sample size in columns 2-4 we pool the British and US data. We confirm the earlier result that the gap is positively correlated with the unemployment rate: we find it now for the two countries. The British dummy is significantly negative in columns 2 and 3 . Once again there is no significant time trend in these data, even though the unemployment rate itself is positively trended. Indeed, the finding of relative constancy of the differential through time in Great Britain seems quite robust ${ }^{15}$. In assessing the impact of unions at the macroeconomic level, it should be kept in mind that, even though the union wage differential appears to have remained roughly constant, it applies to a considerably smaller fraction of the workforce in 1993 than it did ten or twenty years ago. There are now fewer workers getting the ten percent union wage premium than there were.

It is of interest to examine the extent to which the union wage gap varies across groups in the two countries. We have already presented a number of disaggregated results by gender, race and the public/private sector in Tables 1-4 above. Table 9 reports estimates for a number of other categories each derived from separate wage regressions for 1993 for the US and 1993/4 for Great Britain. Wage gaps are the same by race and gender in the US; in contrast in Great Britain nonwhites and women have higher differentials. In all other respects the results appear similar across the two countries; the gap is higher among the young, the least educated, part-timers, non-manuals and for workers in the non-manufacturing sector ${ }^{16}$.

\section{Conclusions}

The main findings of this paper may be summarised as follows.

a) The union wage gap averages $15 \%$ in the US and $10 \%$ in Great Britain. 
b) The gap moves pro-cyclically but appears to be untrended in both countries. Union wages are sticky.

c) The size of the wage gap varies across groups. In boith the US and Great Britain the differential is relatively high in the private sector, in non-manufacturing, for manuals, the young and the least educated.

d) In the US there are no differences by race or gender in the size of the differential. In Great Britain it is higher both for women and non-whites.

In comparison with other countries it does appear that the size of these estimated wage gaps are quite high. Union wage differentials in other countries are generally less than $10 \%$ (see Blanchflower, 1996). It does appear that countries that have experienced rapid declines in union membership do have the highest wage differentials. The fact that the differential has remained more or less constant in both Great Britain and the US is a puzzle, particularly given the rapid declines in union membership in both countries. The evidence is not consistent with the widely held view that union power has been emasculated. We still have a great deal to learn about the time-series properties of the union wage differential and its correlates. 


\section{Endnotes}

1. See Blanchflower (1985).

2. See Blanchflower $(1984,1986 \mathrm{a}, 1986 \mathrm{~b}, 1991,1996)$; Blanchflower and Freeman $(1992$, 1994); Blanchflower and Machin (1996); Blanchflower and Oswald (1990, 1994) and Blanchflower, Oswald and Garrett (1989).

3. Examples of studies for Canada are Simpson (1985) who found $11 \%$ for 1974 ; Grant et al, (1987) with $12-14 \%$ for 1969 and 13-16\% in 1970 and Green (1991) who obtained an estimate of $15 \%$ for 1986.

4. Australian studies include Kornfeld (1993) who found 7-10\% for young people between 1984 and 1987. Mulvey (1986), obtained $7 \%$ for women and $10 \%$ for men using a 1982 sample. Christie (1992) using 1984 data obtained an estimate of $16.6 \%$ using OLS and $17.2 \%$ using simultaneous equation methods. Blanchflower and Freeman (1992) found 8\% for the period 1985-1987.

5. In Blanchflower (1996) I obtained union wage gap estimates based on similar data and specifications for the following countries - * implies not significantly different from zero.

$\begin{array}{lc}\text { Australia } & \% \\ \text { Austria } & 9.2 \\ \text { Canada } & 14.6 \\ \text { Germany } & 4.8^{*} \\ \text { Ireland } & 3.4 \\ \text { Israel } & 30.5 \\ \text { Italy } & 7.0^{*} \\ \text { Japan } & 7.2 \\ \text { Netherlands } & 47.8 \\ \text { New Zealand } & 3.7^{*} \\ \text { Norway } & 8.4 \\ \text { Spain } & 7.7 \\ \text { Switzerland } & 0.3^{*} \\ \end{array}$

The very large estimate for Japan appears to arise because of the lack of controls for workplace/firm size. Some of the estimates are based on only a few hundred observations so care has to be taken in interpreting these results.

6. Blanchflower (1984); Stewart (1987); Blanchflower and Oswald (1990); Blanchflower, Oswald and Garrett (1990); Stewart (1990); Stewart (1991); Metcalf and Stewart (1992); Machin, Stewart and Van Reenan; Stewart (1995) and Blanchflower and Machin (1996).

7. Stewart (1983); Shah (1984); Green (1988); Symons and Walker (1988); Blackaby, Murphy and Sloane (1991); Blanchflower (1991); Main and Reilly (1992); Murphy, Sloane and Blackaby (1992) and Main (1996).

8. Interestingly enough Canada, which has many of the same firms and trade unions that exist in the US, has not seen declines in density -1 1970=31\%, $1980=36.1 \% ; 1990=35.8 \% ; 1993=37.4 \%$ (source: Visser, 1996).

9. In both cases we use edited or computed data, including allocated values. 
10. The dependent variable is usual hourly earnings as defined above. All equations include age and its square, a gender dummy, 3 public sector dummies, 2 self-employment dummies (incorporated and unincorporated), a part-time dummy, 50 state dummies and 49 industry dummies. For the years 1983-1988 2 race dummies were included. After 1989 this was increased to 4. From 1983-1991 a years of schooling variable was used. For 1992 and 1993, because of the change in the sample to a credential based schooling measure, 15 qualification dummies were used. For 1994 and 19956 full-time/part-time dummies were also included.

11. For a discussion on these issues and rather different results for the earlier period 1920-1980 see Pencavel and Hartsog (1984).

12. Chaison and Dhavale (1990) estimate that maintenance of current density levels will require unions to make, over and above current organizing budgets, an expenditure of $\$ 300$ million annually.

13. For further discussion on this point see Blanchflower and Freeman (1992).

14. All years pooled 10\%; $198311 \% ; 198411 \% ; 19851 \%$ (not significant); $198613 \% ; 19879 \%$; $198911 \%$. Dependent variable in Blanchflower (1991) was log of annual earnings. Note that the dependent variable is banded with open-ends. The banding changes over the years. Mid-points are used and the ends are closed in an inevitably ad hoc way.

15. It should be noted however that Gregg and Machin (1992) have found evidence in a sample of large quoted UK firms that union wages increased less than non-union wages. while Ingram (1991) found similar evidence for some sectors. Differences in wage growth is likely to work to reduce union differentials moderately. Lanot and Walker (1997) provide simultaneous equation estimates for an earlier period 1978-1985 and show a marked increase in the size of the wage gap for married male manuals, although they do observe some decline in the differential at the end of the period (see their Figure 3).

16 Due to small sample sizes in the UK it is not appropriate to disaggregate furthe by occupation or industry. The large sample sizes for the US allow further disaggregation. The following estimated wage gaps for 1993 were obtained from separate wage regressions. Sample sizes are also reported in the second column.

Occupation

Executive, administrative \& managerial

Professional specialty occupations

Technicians and related support occupations

$6.0 \% \quad 20,349$

$13.7 \% \quad 24,524$

Sales occupations

$12.3 \% \quad 54,720$

$14.5 \% \quad 18,645$

Administrative support occupations, incl. clerical $\quad 12.0 \% \quad 29,609$

Service occupations

Farming, forestry and fishing

$20.1 \% \quad 24,999$

Machin production, craft and repair

$19.6 \% \quad 17,691$

Machine operators, assembler etc.

$23.6 \% \quad 11,775$

$\begin{array}{lll}\text { Transportation and material moving equipment occs. } & 32.8 \% & 7,428\end{array}$

Handlers, equipment cleaners, helpers \& laborers $\quad 31.6 \% \quad 7,105$

Industry

Agriculture

$13.9 \% \quad 2,534$

Mining

$7.9 \% \quad 1,197$

Construction

$30.0 \% \quad 8,136$ 
Manufacturing

Transportation \& public utilities

Wholesale trade

Retail trade

Finance, insurance and real estate

$2.1 \%$

Business \& repair services

$16.9 \%$

$8.8 \%$

Entertainment \& recreation services

$32.7 \%$

$12.4 \%$

$8.3 \%$

12,752

6,336

29,324

11,318

8,006

Professsional \& related services

5,710

769

Public administration

43,265

9,486 


\section{References}

Bender, K. A., (1996). 'The changing determinants of U.S. unionism: an analysis using worker-level data', Joumal of Labor Research, forthcoming.

Blackaby, D.H., P.D. Murphy and P.J. Sloane, (1991). 'Union membership, collective bargaining coverage and the trade union mark-up for Britain, Economics Letters, 36(2), June, pp. 203-208.

Blanchflower, D. G. (1984), 'Union relative wage effects: a cross-section analysis using establishment data',British Journal of Industrial Relations, 22, pp. 311-332.

Blanchflower, D. G. (1985), 'Union relative wage effects: a cross-section analysis using establishment data from the 1980 Workplace Industrial Relations Survey', unpublished Ph.D. thesis, Queen Mary College, University of London.

Blanchflower, D. G. (1986a), 'Wages and concentration in Great Britain.' Applied Economics, vol. 18, 1986, pp. 1025-1038.

Blanchflower, D. G. (1986b), "What effect do unions have on relative wages in Great Britain?' British Journal of Industrial Relations, vol. 24, 1986, pp. 196-204.

Blanchflower, D. G. (1991), 'Fear, unemployment and pay flexibility.' Economic Journal, March, pp. 483-496.

Blanchflower, D. G. (1996), 'The role and influence of trade unions in the OECD', Centre for Economic Performance Discussion Paper No.?

Blanchflower, D.G and R.B. Freeman, (1992). 'Unionism in the US and other advanced OECD countries', Industrial Relations, Winter 1992, pp. 56-79 reprinted in Labor Market Institutions and the Future Role of Unions edited by M. Bognanno and M. Kleiner, Blackwell.

Blanchflower, D.G and R.B. Freeman, (1994). 'Did the Thatcher reforms change British labour market performance?', in R. Barrell (Ed.) The UK labour market. Comparative aspects and institutional developments. Cambridge University Press.

Blanchflower, D.G., and S. Machin, (1996). 'Product market competition, wages and productivity: international evidence from establishment level data', Annales d'Economie et de Statistique 41/42, June, pp. 219-254.

Blanchflower, D.G and Oswald, A.J., (1990). 'The determination of white collar pay', Oxford Economic Papers, 42, pp. 356-378.

Blanchflower, D.G and Oswald, A.J., (1994). The wage curve, MIT Press, Cambridge, Mass..

Blanchflower, D.G., Oswald, A.J., and Garrett, M. (1989), 'Insider power and wage determination', Economica, 57, pp. 143-170.

Booth, A. (1995). The economics of the trade union, Cambridge University Press, Cambridge, England.

Chaison, G.N. and D.G. Dhavale (1990). 'A note on the severity of the decline in union organizing activity', Industrial and Labor Relations Review, 43(4), pp. 366-373. 
Christie, V, (1992). 'Union wage effects and the probability of union membership', Economic Record, March, pp. 43-56

Farber, H.S., (1990). 'The decline of unionization in the United States: what can be learned from recent experience?, Journal of Labor Economics, 8(1, pt.2), pp. S75-S105.

Freeman, R.B.. (1984). "A longitudinal analysis of the effects of trade unions', Journal of Labor Economics, 2, January, pp. 1-26.

Freeman, R.B.. (1989). Labor markets in action, Harvard University Press, Cambridge, Massachusetts.

Freeman, R.B. and L. Katz (eds.) (1995). Differences and changes in wage structures. published by University of Chicago Press and NBER, pp. 25-65.

Freeman, R.B. and J. Medoff, (1984). What do unions do?, Basic Books, New York.

Grant, E. K., Swidinsky, R. and J. Vanderkamp, (1987). 'Canadian union-nonunion wage differentials, Industrial and Labor Relations Review; 41(1), October pp. 93-107.

Green, D.A., (1991). 'A comparison of estimation approaches for the union-nonunion wage differential', University of British Columbia Department of Economics Discussion Paper: 91-13, May.

Green, F., (1988). 'The trade union wage gap in Britain: some recent estimates', Economics Letters, 27, pp.183-187.

Ingram, P., (1991). 'Ten years of wage settlements', Oxford Review of Economic Policy, 7 , March, pp. 93-106.

Jarrell, S.B., and T.D. Stanley, (1990). 'A meta-analysis of the union-nonunion wage gap', Industrial and Labor Relations Review 44(1), pp. 54-67.

Katz, L., G. Loveman, and D. G. Blanchflower, (1995). 'A comparison of changes in the structure of wages in four OECD countries', in Differences and changes in wage structures edited by Larry Katz and Richard Freeman and published by University of Chicago Press and NBER, pp. 25-65.

Komfeld, R., (1993). 'The effects of union membership on wages and employee benefits: the case of Australia', Industrial and Labor Relations Review, 47(1), October pp. 114-28.

Lanot, G. and I. Walker (1997), 'The union/non-union wage differential: an application of semiparametric methods', Journal of Econometrics, (forthcoming).

Lewis, H. G., (1963). Unionism and relative wages in the United States, University of Chicago Press, Chicago.

Lewis, H. G., (1986). Union relative wage effects; a survey, University of Chicago Press, Chicago.

Linneman, P.D. and M.L. Wachter, (1986). 'Rising union premiums and the declining boundaries between competing groups', American Economic Review Papers and Proceedings, May, 76, 103-8 
Linneman, P.D., M.L. Wachter and W.H. Carter, (1990). 'Evaluating the evidence on union employment and wages', Industrial and Labor Relations Review 44(1), pp. 34-53.

Machin, S, M. B. Stewart, and J. Van Reenan (1993). 'The economic effects of multiple unionism', Scandinavian Journal of Economics, 95(3), pp. 275-292.

Main, B, (1996). 'The union relative wage gap', in Trade unionism in recession, edited by D. Gallie, R. Penn and M. Rose, Oxford University Press, Oxford.

Main, B. and B. Reilly, (1992). 'Women and the union wage gap, Economic Journal, 102(410), January, pp. 49-66.

Main, B. and B. Reilly, (1993). 'The employer size-wage gap: Evidence for Britain, Economica, 60(238), May, pp. 125-42.

Metcalf, D. and M.B. Stewart (1992). 'Closed shops and relative pay: institutional arrangements or high density?', Oxford Bulletin of Economics and Statistics, 54(4) pp. 503-516..

Minford, P. (1983), Unemployment: cause and cure Martin Robertson.

Moll, P., (1993). 'Black South African unions: relative wage effects in international perspective', Industrial and Labor Relations Review, 46(2), pp. 245-262.

Mulvey, C., (1986). 'Wage levels: do unions make a difference?' in Wage fixation in Australia edited by J. Niland, Allen \& Unwin, Sydney.

Park, Y., (1991). 'Union/non-union wage differentials in the Korean manufacturing sector', International Economic Journal, 5(4), pp. 79-91.

Pencavel J. and C.E. Hartsog, (1984). 'A reconsideration of the effects of unionism on relative wages and employment in the United States, 1920-1980, Journal of Labor Economics, 2(2), pp. 193-232.

Schmidt, C., (1995). 'Relative wage effects of German unions', mimeo, Selapo, University of Munich.

Schmidt, C. and K. F. Zimmermann, (1995). 'Work characteristics, firm size and wages', Review of Economics and Statistics, 73, pp. 705-710.

Shah, A., (1984). 'Job attributes and the size of the union/non-union wage differential', Economica, 51, pp. 437-446.

Simpson, W., (1985). 'The impact of unions on the structure of Canadian wages, an empirical analysis with microdata', Canadian Joumal of Economics, 18(1), pp. 164-181.

Stewart, M.B., (1983). 'Relative earnings and individual union membership in the United Kingdom', Economica, 50, no. 198, pp. 111-125.

Stewart, M.B., (1987). 'Collective bargaining arrangements, closed shops and relative pay', Economic Journal, 97, pp.140-156.

Stewart, M.B., (1990). 'Union wage differentials, product market influences and the division of rents', Economic Journal, 100, pp.1122-37 
Stewart, M.B. (1991), 'Union wage differentials in the face of changes in the economic and legal environment', Economica, 58,, pp. 155-172.

Stewart, M.B., (1995). 'Union wage differentials in an era of declining unionization Oxford Bulletin of Economics and Statistics; 57(2), May, pp. 143-66.

Symons, E. and Walker, I., (1988), 'Union/non-union wage differentials, 1979-1984: Evidence From the UK Family Expenditure Surveys', mimeo, Keele University.

Wagner, J. (1991). 'Gewerkschaftsmitgliedschaft und arbeitseinkommen in der Bundesrepublik Deutschland', Ifo-Studen, pp. 109-140. 
Table 1. Log hourly earnings equations, USA, 1983.

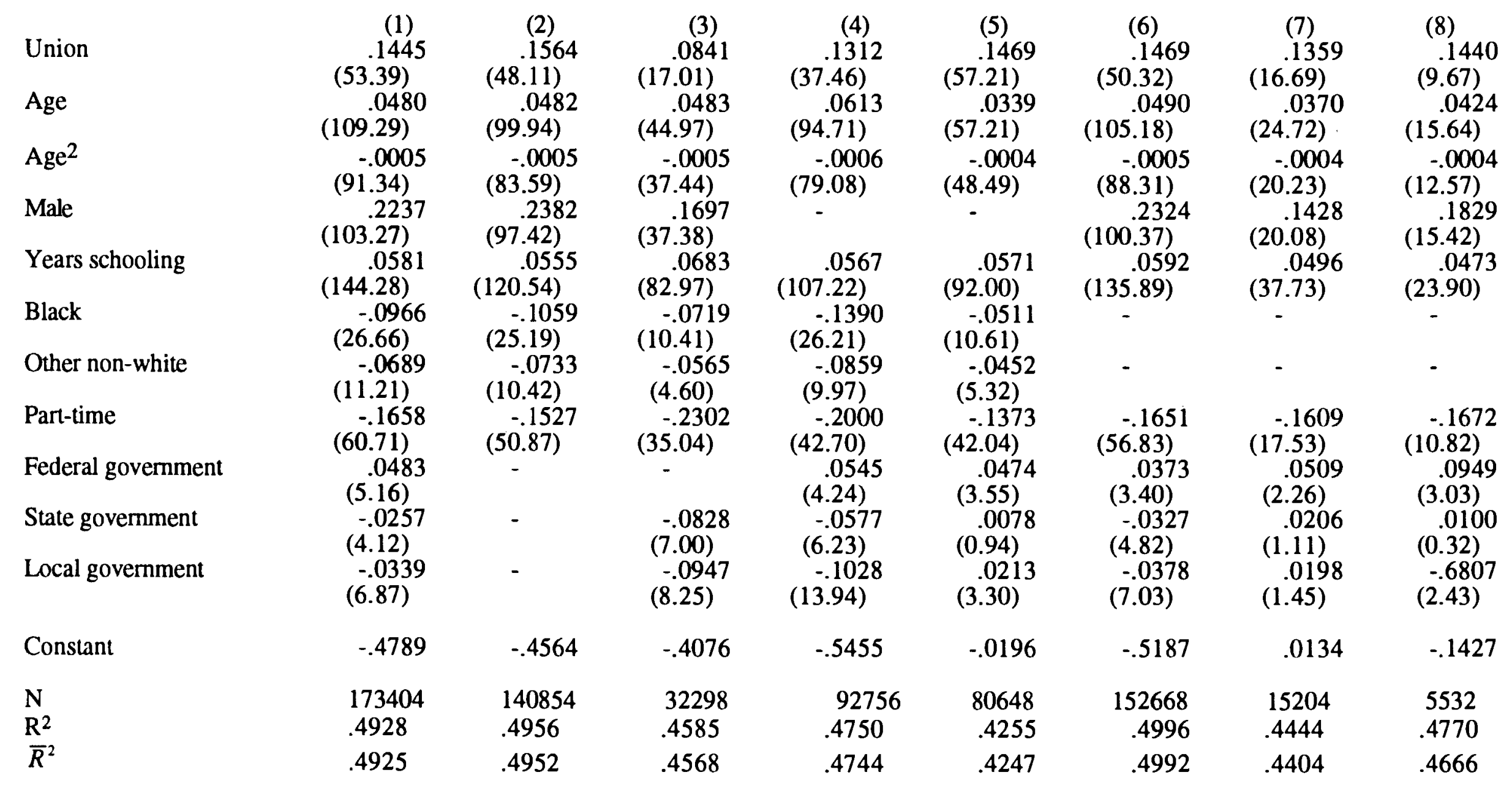

Notes: Private sector subsample excludes self-employed. All equations include 50 state and 50 industry dummies +2 self-employment dummies. t-statistics in parentheses.

Source: CPS Outgoing Rotation Group File, 1993: NBER 50 Variable Uniform Extract 1979-1993. 
Table 2. Log hourly earnings equations USA, 1993.

\begin{tabular}{|c|c|c|c|c|c|c|c|c|}
\hline 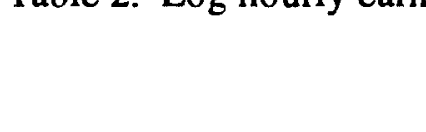 & All & $\begin{array}{c}\text { (2) } \\
\text { Private sector }\end{array}$ & $\begin{array}{l}(3) \\
\text { Public sector }\end{array}$ & $\begin{array}{l}\text { (4) } \\
\text { Men }\end{array}$ & $\begin{array}{c}(5) \\
\text { Women }\end{array}$ & $\begin{array}{c}(6) \\
\text { Whites }\end{array}$ & $\begin{array}{c}(7) \\
\text { Blacks }\end{array}$ & $\begin{array}{l}\quad(8) \\
\text { Other non } \\
\text {-whites }\end{array}$ \\
\hline Union & $\begin{array}{l}.1440 \\
(45.99)\end{array}$ & $(38.25)$ & $(20.63)$ & $(33.68)$ & $\begin{array}{l}.1306 \\
(27.91)\end{array}$ & $(42.05)$ & $(16.01)$ & $\begin{array}{l}.1455 \\
(9.94)\end{array}$ \\
\hline Age & $\begin{array}{l}.0430 \\
(89.34)\end{array}$ & $\begin{array}{l}.0433 \\
(82.05)\end{array}$ & $\begin{array}{l}.0444 \\
(36.59)\end{array}$ & $\begin{array}{l}.0507 \\
(69.33)\end{array}$ & $\begin{array}{l}.0473 \\
(54.74)\end{array}$ & $\begin{array}{c}.0444 \\
(85.85)\end{array}$ & $\begin{array}{l}.0340 \\
(21.85)\end{array}$ & $\begin{array}{l}.0357 \\
(14.76)\end{array}$ \\
\hline $\mathrm{Age}^{2}$ & $\begin{array}{c}-.0004 \\
(74.89)\end{array}$ & $\begin{array}{l}-.0004 \\
(69.01)\end{array}$ & $\begin{array}{c}-.0004 \\
(30.66)\end{array}$ & $\begin{array}{l}-.0005 \\
(56.17)\end{array}$ & $\begin{array}{c}-.0004 \\
(47.44)\end{array}$ & $\begin{array}{c}-.0004 \\
(72.11)\end{array}$ & $\begin{array}{l}-.0003 \\
(18.17)\end{array}$ & $\begin{array}{l}-.0004 \\
(12.54)\end{array}$ \\
\hline Male & $\begin{array}{l}.1423 \\
(59.33)\end{array}$ & $\begin{array}{l}.1524 \\
(57.08)\end{array}$ & $(19.02)$ & - & - & $\begin{array}{c}.1537 \\
(58.93)\end{array}$ & $\begin{array}{l}.0576 \\
(7.79)\end{array}$ & $(10.32)$ \\
\hline Veteran & ${ }^{(4.01)}$ & $\begin{array}{c}.0159 \\
(4.04)\end{array}$ & $\begin{array}{l}.0161 \\
(2.19)\end{array}$ & $\begin{array}{l}-.0201 \\
(5.13)\end{array}$ & $\begin{array}{l}-.0048 \\
(0.36)\end{array}$ & $\begin{array}{l}.0093 \\
(2.50)\end{array}$ & $\begin{array}{l}.0341 \\
(3.04)\end{array}$ & $\begin{array}{l}.0325 \\
(1.54)\end{array}$ \\
\hline Federal government & $(13.67)$ & - & - & $\begin{array}{l}.0859 \\
(8.66)\end{array}$ & $(11.65)$ & $(12.30)$ & $\begin{array}{l}.1012 \\
(5.81)\end{array}$ & $\begin{array}{c}.0873 \\
(3.21)\end{array}$ \\
\hline State government & $\begin{array}{l}-.0194 \\
(3.28)\end{array}$ & - & $\begin{array}{c}-.1070 \\
(12.27)\end{array}$ & $\begin{array}{l}-.0411 \\
(4.59)\end{array}$ & $\begin{array}{l}.0128 \\
(1.64)\end{array}$ & $\begin{array}{l}-.0208 \\
(3.15)\end{array}$ & $\begin{array}{l}.0173 \\
(1.08)\end{array}$ & $\begin{array}{l}-.0469 \\
(1.80)\end{array}$ \\
\hline Local government & $\begin{array}{l}-.0288 \\
(5.73)\end{array}$ & - & $\begin{array}{l}-.1278 \\
(14.75)\end{array}$ & $\begin{array}{l}-.0621 \\
(8.09)\end{array}$ & $\begin{array}{l}.0062 \\
(0.95)\end{array}$ & $\begin{array}{l}-.0381 \\
(6.79)\end{array}$ & $\begin{array}{l}.0183 \\
(1.39)\end{array}$ & $\begin{array}{c}.0281 \\
(1.22)\end{array}$ \\
\hline Black & $\begin{array}{c}.1237 \\
(33.63)\end{array}$ & $\begin{array}{l}-.1343 \\
(31.70)\end{array}$ & $\begin{array}{c}-.0896 \\
(12.36)\end{array}$ & $\begin{array}{r}-.1674 \\
(33.01)\end{array}$ & $\begin{array}{l}-.0805 \\
(16.80)\end{array}$ & - & - & - \\
\hline American Indian & $\begin{array}{l}-.0471 \\
(4.34)\end{array}$ & $\begin{array}{l}-.0683 \\
(5.08)\end{array}$ & $\begin{array}{l}-.0026 \\
(0.14)\end{array}$ & $\begin{array}{l}-.0459 \\
(2.95)\end{array}$ & $\begin{array}{l}-.0421 \\
(2.83)\end{array}$ & - & - & - \\
\hline Asian or Pacific Islander & $\begin{array}{c}-.0919 \\
(14.60)\end{array}$ & $\begin{array}{c}-.0947 \\
(13.60)\end{array}$ & $\begin{array}{l}-.0738 \\
(5.06)\end{array}$ & $\begin{array}{l}-.1064 \\
(11.85)\end{array}$ & $\begin{array}{l}-.0731 \\
(8.43)\end{array}$ & - & - & $\begin{array}{l}-.0202 \\
(1.19)\end{array}$ \\
\hline Other non-white & $\begin{array}{l}-.0900 \\
(6.13)\end{array}$ & $\begin{array}{l}-.1003 \\
(6.28)\end{array}$ & $\begin{array}{l}-.0247 \\
(0.66)\end{array}$ & $\begin{array}{l}-.0915 \\
(4.58)\end{array}$ & $\begin{array}{c}-.0797 \\
(3.73)\end{array}$ & - & - & $\begin{array}{c}-.0441 \\
(2.06)\end{array}$ \\
\hline Part-time & $\begin{array}{l}-.1772 \\
(61.29)\end{array}$ & $\begin{array}{c}-.1674 \\
(52.62)\end{array}$ & $\begin{array}{c}-.2227 \\
(32.04)\end{array}$ & $\begin{array}{l}-.2280 \\
(44.58)\end{array}$ & $\begin{array}{c}-.1473 \\
(42.97)\end{array}$ & $\begin{array}{c}-.1755 \\
(56.28)\end{array}$ & $\begin{array}{c}-.1908 \\
(20.20)\end{array}$ & $\begin{array}{c}-.1550 \\
(11.46)\end{array}$ \\
\hline Constant & .3428 & .4444 & -.5819 & .2608 & .6319 & .2274 & .5972 & .7909 \\
\hline $\begin{array}{l}\mathrm{N} \\
\mathrm{R}^{2}\end{array}$ & $\begin{array}{l}171439 \\
.4172\end{array}$ & $\begin{array}{c}140323 \\
.4637\end{array}$ & $\begin{array}{c}147479 \\
.4748\end{array}$ & $\begin{array}{l}87257 \\
.4682\end{array}$ & $\begin{array}{l}84182 \\
.4480\end{array}$ & $\begin{array}{l}147479 \\
.4748\end{array}$ & $\begin{array}{l}15969 \\
.4396\end{array}$ & $\begin{array}{l}7991 \\
.4706\end{array}$ \\
\hline $\bar{R}^{2}$ & .4708 & 4632 & .4743 & .4675 & .4471 & .4743 & .4352 & .4622 \\
\hline
\end{tabular}

Notes: All equations also include 15 schooling dummies, 50 state dummies and 50 industry dummies and 2 self-employment dummies.

Excluded categories are private sector and white. Private sector excludes the self-employed. $\mathrm{t}$-statistics in parentheses.

Source: CPS Outgoing Rotation Group File, 1993: NBER 50 Variable Uniform Extract 1979-1993 
Table 3. Time series union wage gap regressions, USA, 1967-1995

\begin{tabular}{|c|c|c|c|c|c|c|}
\hline & (1) & (2) & (3) & (4) & (5) & (6) \\
\hline Unemployment rate $t$ & $\begin{array}{l}.5500 \\
(2.78)\end{array}$ & & $\begin{array}{c}.0021 \\
(0.01)\end{array}$ & & & \\
\hline $\begin{array}{l}\text { Unemployment rate } t-1 \\
\text { Union wage gap t-1 }\end{array}$ & & $\begin{array}{l}.8090 \\
(4.80)\end{array}$ & $\begin{array}{l}.8076 \\
(3.46)\end{array}$ & $\begin{array}{l}.6946 \\
(3.63) \\
.2008 \\
(1.22)\end{array}$ & $\begin{array}{l}.5491 \\
(3.10)\end{array}$ & $\begin{array}{l}.7408 \\
(4.26)\end{array}$ \\
\hline CPI & & & & & & $\begin{array}{c}.0013 \\
(0.02)\end{array}$ \\
\hline Time trend & $\begin{array}{l}-.0201 \\
(0.62)\end{array}$ & $\begin{array}{l}-.0539 \\
(1.87)\end{array}$ & $\begin{array}{c}-.0539 \\
(1.83)\end{array}$ & $\begin{array}{l}-.0487 \\
(1.69)\end{array}$ & $\begin{array}{l}.2413 \\
(1.43)\end{array}$ & $\begin{array}{l}-.0587 \\
(1.84)\end{array}$ \\
\hline Constant & 11.9905 & 10.9027 & 10.8984 & 8.5025 & 8.0924 & 11.2538 \\
\hline $\begin{array}{l}\mathrm{N} \\
\mathrm{R}^{2} \\
\text { Adjusted } \mathrm{R}^{2}\end{array}$ & $\begin{array}{l}28 \\
.2421 \\
.1814\end{array}$ & $\begin{array}{l}27 \\
.4901 \\
.4476\end{array}$ & $\begin{array}{l}27 \\
.4901 \\
.4235\end{array}$ & $\begin{array}{l}27 \\
.5211 \\
.4587\end{array}$ & $\begin{array}{l}27 \\
.4619 \\
.4170\end{array}$ & $\begin{array}{l}27 \\
.4410 \\
.3681\end{array}$ \\
\hline
\end{tabular}

t-statistics in parentheses. 
Table 4. Log hourly earnings equations, Great Britain, 1983

\begin{tabular}{|c|c|c|c|c|c|}
\hline & (1) & (2) & (3) & (4) & (5) \\
\hline Union & $\begin{array}{c}\text { All } \\
.1064 \\
(10.23)\end{array}$ & $\begin{array}{c}\text { Private sector } \\
.0973 \\
(7.20)\end{array}$ & $\begin{array}{c}\text { Public sector } \\
.0960 \\
(5.86)\end{array}$ & $\begin{array}{c}\text { Males } \\
.0821 \\
(5.78)\end{array}$ & $\begin{array}{c}\text { Females } \\
.1176 \\
(7.89)\end{array}$ \\
\hline Age & $\begin{array}{l}.0646 \\
(30.83)\end{array}$ & $\begin{array}{c}.0670 \\
(26.07)\end{array}$ & $\begin{array}{c}.0543 \\
(14.81)\end{array}$ & $\begin{array}{c}.0842 \\
(28.15)\end{array}$ & $\begin{array}{c}.0449 \\
(14.94)\end{array}$ \\
\hline $\mathrm{Age}^{2}$ & $\begin{array}{l}-.0007 \\
(27.34)\end{array}$ & $\begin{array}{l}-.0007 \\
(23.03)\end{array}$ & $\begin{array}{c}-.0006 \\
(13.05)\end{array}$ & $\begin{array}{l}-.0009 \\
(25.28)\end{array}$ & $\begin{array}{l}-.0005 \\
(13.20)\end{array}$ \\
\hline Male & $\begin{array}{c}.2987 \\
(27.63)\end{array}$ & $\begin{array}{l}.3140 \\
(22.43)\end{array}$ & $\begin{array}{c}.2865 \\
(17.28)\end{array}$ & - & - \\
\hline Part-time & $\begin{array}{r}-.0795 \\
(6.30)\end{array}$ & $\begin{array}{c}-.0981 \\
(5.87)\end{array}$ & $\begin{array}{l}-.0405 \\
(2.18)\end{array}$ & $\begin{array}{l}-.0480 \\
(1.54)\end{array}$ & $\begin{array}{l}-.0379 \\
(2.71)\end{array}$ \\
\hline Black & $\begin{array}{l}-.1030 \\
(3.91)\end{array}$ & $\begin{array}{l}-.1387 \\
(4.01)\end{array}$ & $\begin{array}{l}-.0406 \\
(1.04)\end{array}$ & $\begin{array}{l}-.1199 \\
(3.62)\end{array}$ & $\begin{array}{c}-.0692 \\
(1.63)\end{array}$ \\
\hline Public sector & $\begin{array}{l}.0509 \\
(4.79)\end{array}$ & - & - & $\begin{array}{l}.0219 \\
(1.18)\end{array}$ & $\begin{array}{l}.1046 \\
(5.00)\end{array}$ \\
\hline Constant & -.3995 & -.7158 & -.5495 & -.7316 & -.0306 \\
\hline $\begin{array}{l}\mathrm{N} \\
\mathrm{R}^{2}\end{array}$ & $\begin{array}{l}7951 \\
.5260\end{array}$ & $\begin{array}{l}5106 \\
.4992\end{array}$ & $\begin{array}{r}2845 \\
.5493\end{array}$ & $\begin{array}{l}4442 \\
.4586\end{array}$ & $\begin{array}{l}3509 \\
.4617\end{array}$ \\
\hline $\bar{R}^{2}$ & .5226 & .4938 & .5404 & .4518 & .4532 \\
\hline
\end{tabular}

Source: General Household Survey, 1983.

Notes: equations include 17 highest qualification dummies, 4 size of establishment dummies, 11 month dummies, 10 region dummies and 10 industry dummies.

t-statistics in parentheses. 
Table 5. Log hourly earnings equations, Great Britain, 1993-1994 (Source: 1993/4 LFS)

Union (1) (2) All Private sector

Age

$\begin{array}{cc}.0934 & .0990 \\ (11.31) & (9.36) \\ .0618 & .0656\end{array}$

(3)
Public sector
.0806

(4) .0584

Age

$(31.22)$

Age $^{2}$

$-.0007$

Male

Part-time

(26.69)

.1812

(20.65)

-.0974
$10.40)$

Black

$$
\begin{aligned}
& -.1006 \\
& (2.94)
\end{aligned}
$$$$
-.1065
$$

Asian

Other

Public sector - type nk

(3.77)

$-.1151$

(2.94)

.0983

Nationalised industry

$$
\begin{gathered}
(5.48) \\
.0900 \\
(2.72)
\end{gathered}
$$

Central government

(28.40)

6.15)

$$
-.0007
$$$$
\text { (24.11) }
$$

$$
.1814
$$

(17.66)

$$
\begin{aligned}
& -.1062 \\
& (6.88)
\end{aligned}
$$$$
-.0983
$$$$
\text { (2.08) }
$$

$$
\begin{aligned}
& .0142 \\
& (0.26) \\
& -.0765
\end{aligned}
$$$$
-.0765
$$$$
\text { (1.26) }
$$

.0449
$(10.91)$

$$
\begin{aligned}
& -.0005 \\
& (9.48)
\end{aligned}
$$

.1782
$12.32)$

(12.32)

-.0979
$(6.28)$

$-.0948$

(2.00)

.0121

$(0.22)$

$-.0803$

(1.32)

$-$

$$
\text { - }
$$

.0509
$(1.24)$

(5.14)

.0800

$(5)$
Female
.1177
$(9.78)$
.0484

(6)

1993

(7.48)

.0662

(23.72)

$-.0009$

(24.20)

-

$-.0873$

(3.89)

-.1701
$(3.28)$

$-.1810$

(4.98)

$-.1231$

(2.19)

.0667

(3.18)

.0948

.1607

(7.30)

.0902
$6.17)$

Local government

.0246

(0.86)

(2.32)

.0787

-.0618
$(2.39)$

$(2.39)$
-.0902

(2.70)

-.0303
$(1.04)$

$(1.04)$
-.0771

(1.50)

4807

.3669

(2.33)

.0427
$(1.52)$

$-.0227$

(0.46)

(8.31)

.0496
$1.03)$

$\mathrm{N}$
$\mathrm{R}^{2}$

16159
.4108
4078

11352

.4077

.3561

(0.41)

$-.1413$

(1.51)

8014

.4055

.3995

$-.0006$

(14.48)

$-.0007$

(20.68)

.1984

(14.74)

$-.0917$

(6.97)

$-.1687$

(3.40)

$-.0899$

(2.22)

$-.1637$

(3.26)

.1023

(5.05)

(0.75)

.0890

(1.61)

.0554
$(0.71)$

$(0.71)$
.2360

(6.07)

(7.83)

.1207

(6.91)

.0986

(2.98)

.2026

(9.16)

.1174

(2.09)

8145

.3656

.1049

(4.77)

.0721

(1.55)

.1907

(6.67)

.0376

(0.53)

8131

.4217

.3593

Notes: equations also include 11 region dummies, 31 qualification dummies, 11 industry dummies, 6 size of

.4160

establishment dummies and a year dummy. t-statistics in parentheses. Source: Labour Force Surveys 1993/1994. 
Table 6. British Household Panel Study Hourly Earnings Equations.

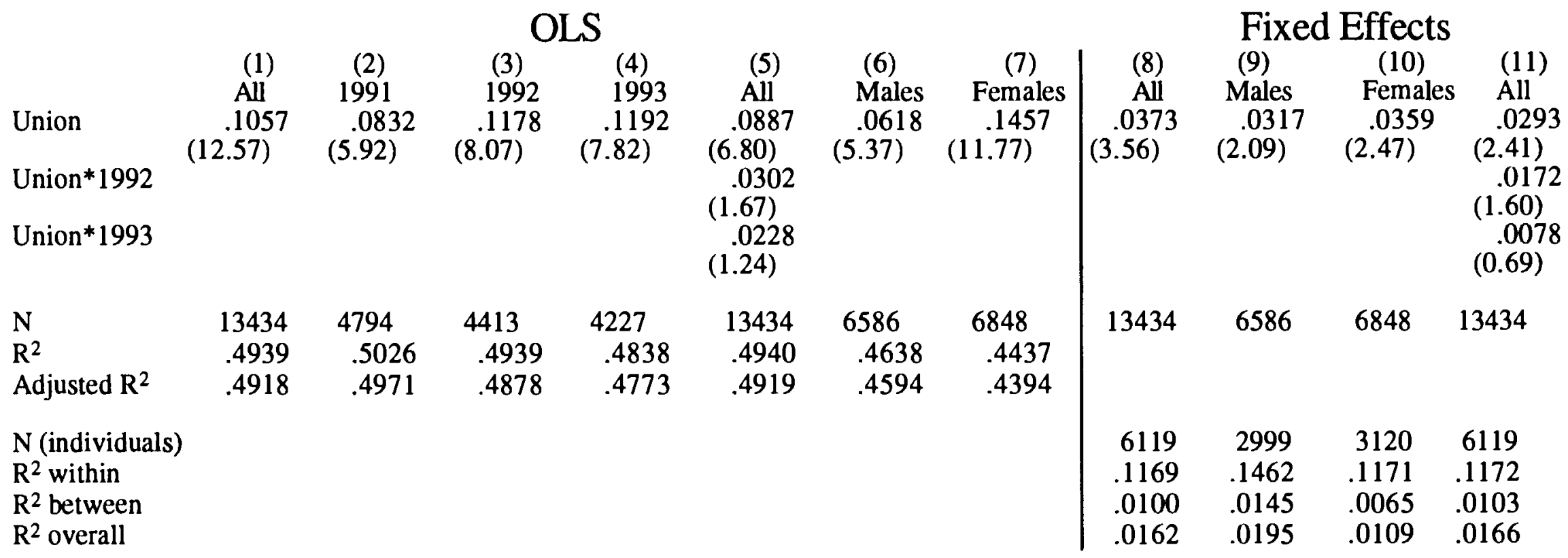

Note: unless otherwise stated controls also included in each equation were age and its square, male dummy, 2 year dummies, part-time dummy, 11 highest qualification dummies, 17 region dummies, 9 industry dummies, and 10 size of establishment dummies.

$\mathrm{N}$ (individuals) refers to the number of people specific fixed effects in the regression

Source: British Household Panel Study, 1991-1993 (waves 1-3), current employees only. 
Table 7. British Social Attitudes Survey Eamings Equations.

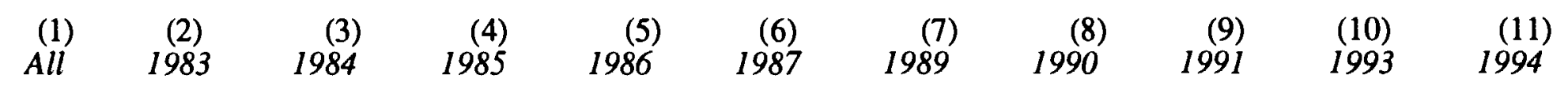

a) Annual (83-94)

$\begin{array}{lccccccccccc}\text { Union } & .1174 & .0995 & .1187 & .0489 & .1516 & .1114 & .1005 & .0890 & .0929 & .1941 & .1319 \\ & (11.92) & (2.62) & (3.20) & (1.38) & (5.80) & (4.04) & (3.70) & (3.51) & (3.74) & (5.04) & (3.69) \\ \mathrm{N} & 10850 & 691 & 699 & 781 & 1418 & 1282 & 1352 & 1177 & 1104 & 1019 & 1327 \\ \mathrm{R}^{2} & .6698 & .6628 & .6605 & .6838 & .6952 & .6835 & .6771 & .6623 & .6366 & .5539 & .5021 \\ \text { Adjusted R }{ }^{2} & .6687 & .6496 & .6474 & .6729 & .6895 & .6770 & .6707 & .6546 & .6278 & .5422 & .4921\end{array}$

b) Hourly (85-94)

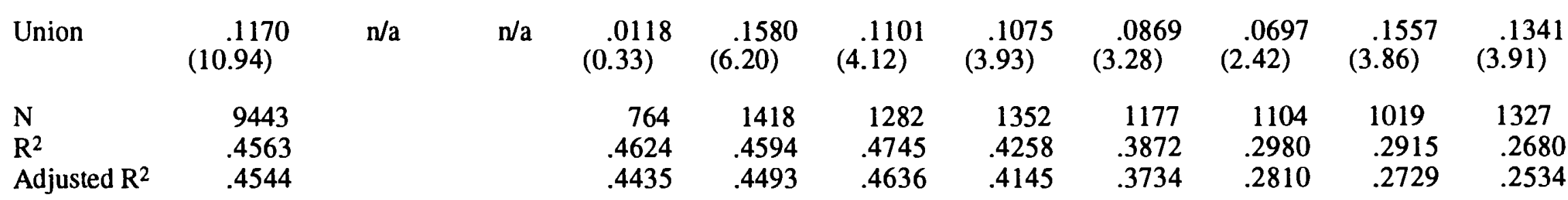

Note: unless otherwise stated controls also included in each equation were age and its square, male dummy, part-time dummy, years of schooling, 10 region dummies, 9 industry dummies, a manual dummy and, in the overall equations, 9 year dummies.

$\mathrm{t}$-statistics in parentheses.

Source: British Social Attitudes Surveys, 1983-1994, current employees only. 
Table 8. Time series union wage gap regressions, USA (1967-1995) and Great Britain, (1983-1994)

$\begin{array}{lccc} & (1) & (2) & (3) \\ \text { Unemployment rate t-1 } & .8732 & .5542 & .6337 \\ & (1.08) & (2.13) & (2.40) \\ \text { Time trend } & .6685 & -.0189 & -.0200 \\ \text { GB dummy } & (1.22) & (0.33) & (0.36) \\ & & -6.2492 & -7.5024 \\ \text { Union wage gap t-1 } & & (4.53) & (4.51) \\ & & & -.2224 \\ \text { Constant } & & & (1.32) \\ \text { N } & -1.9770 & 11.8497 & 14.7071 \\ \mathrm{R}^{2} & & & \\ \text { Adjusted } \mathrm{R}^{2} & 9 & 36 & 36 \\ \text { Sample } & .2366 & .4603 & .4888 \\ & -.0179 & .4097 & .4229 \\ & \text { GB only } & \text { GB+USA } & \text { GB+USA }\end{array}$

t-statistics in parentheses. 
Table 9. Disaggregated union wage gap estimates, USA and UK (\%)

All

Male

Female

Age $<30$

Age $\geq 30 \&<50$

Age $\geq 50$

Public sector

Private sector

Least educated

Middle educated

Most educated

Non-whites

Whites

Part-timers

Full-timers

Manufacturing

Non-manufacturing

Manual

Non-manual

$\begin{array}{rr}U K & U S A \\ 9.8 & 15.5 \\ 6.0 & 15.3 \\ 12.5 & 14.0 \\ 12.6 & 18.8 \\ 8.0 & 14.5 \\ 7.1 & 12.4 \\ 8.4 & 11.8 \\ 10.4 & 16.2 \\ 11.1 & 25.4 \\ 11.1 & 17.1 \\ 4.3 & 9.0 \\ 16.1 & 15.7 \\ 9.6 & 15.5 \\ 14.8 & 30.3 \\ 7.8 & 13.2 \\ 8.3 & 7.0 \\ 17.5 & 10.2 \\ 18.8 & 24.2 \\ 6.7 & 12.2\end{array}$

Notes: 'least educated' is defined as at least 11 years of schooling in the UK and not graduated from high school in the US. 'middle educated' is defined as 12-15 years of schooling in the UK and graduated from high school/some college in the US. 'most educated' is defined as at least 16 years of schooling in the UK and completed college in the US.

'manual' in the US includes forestry and logging occupations. 
Figure 1. Unemployment Rates (\%) in the UK and the US, 1965-1995.

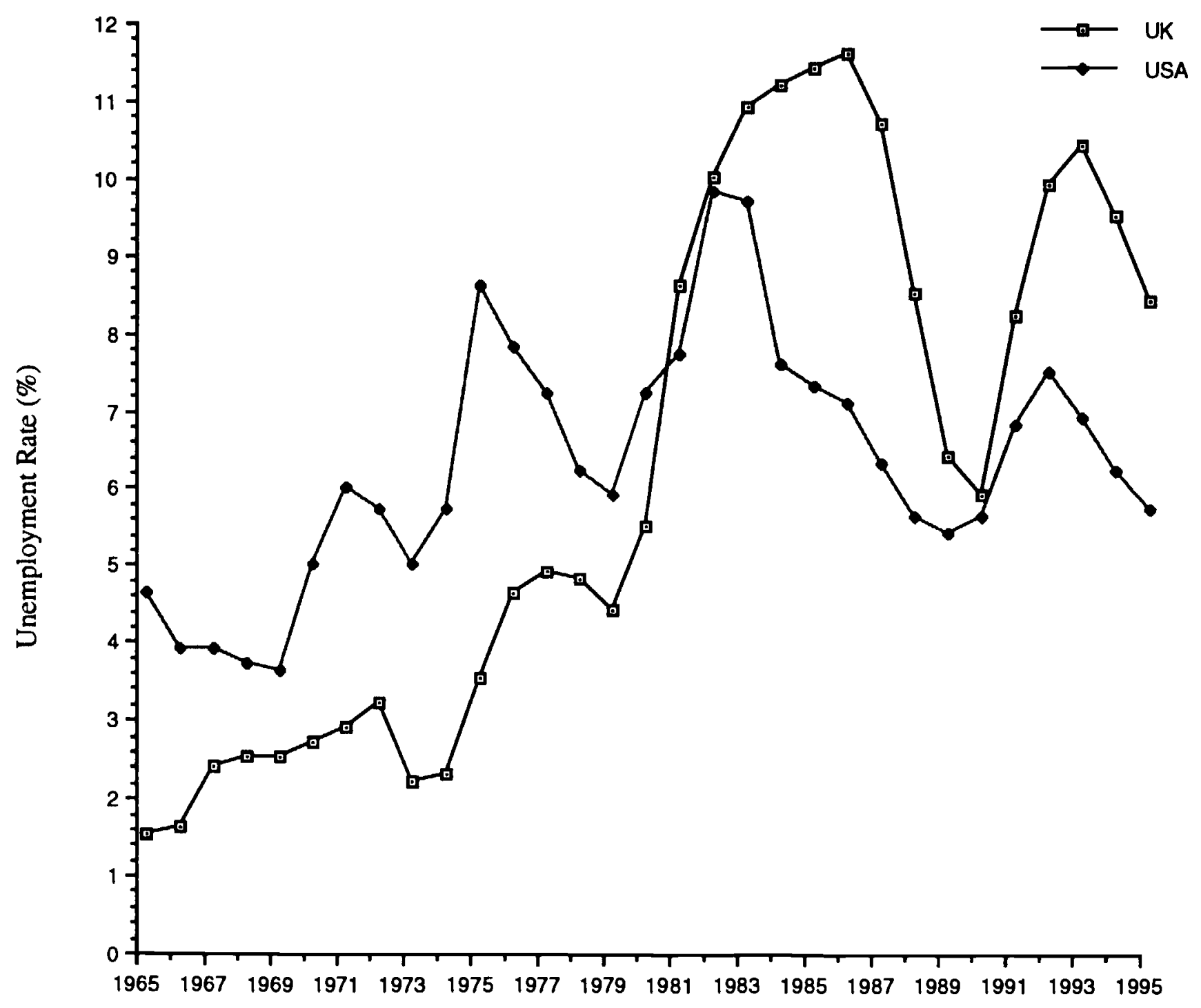

Years 
Figure 2a. Changes in Earnings Inequality. United States, 1967-1989

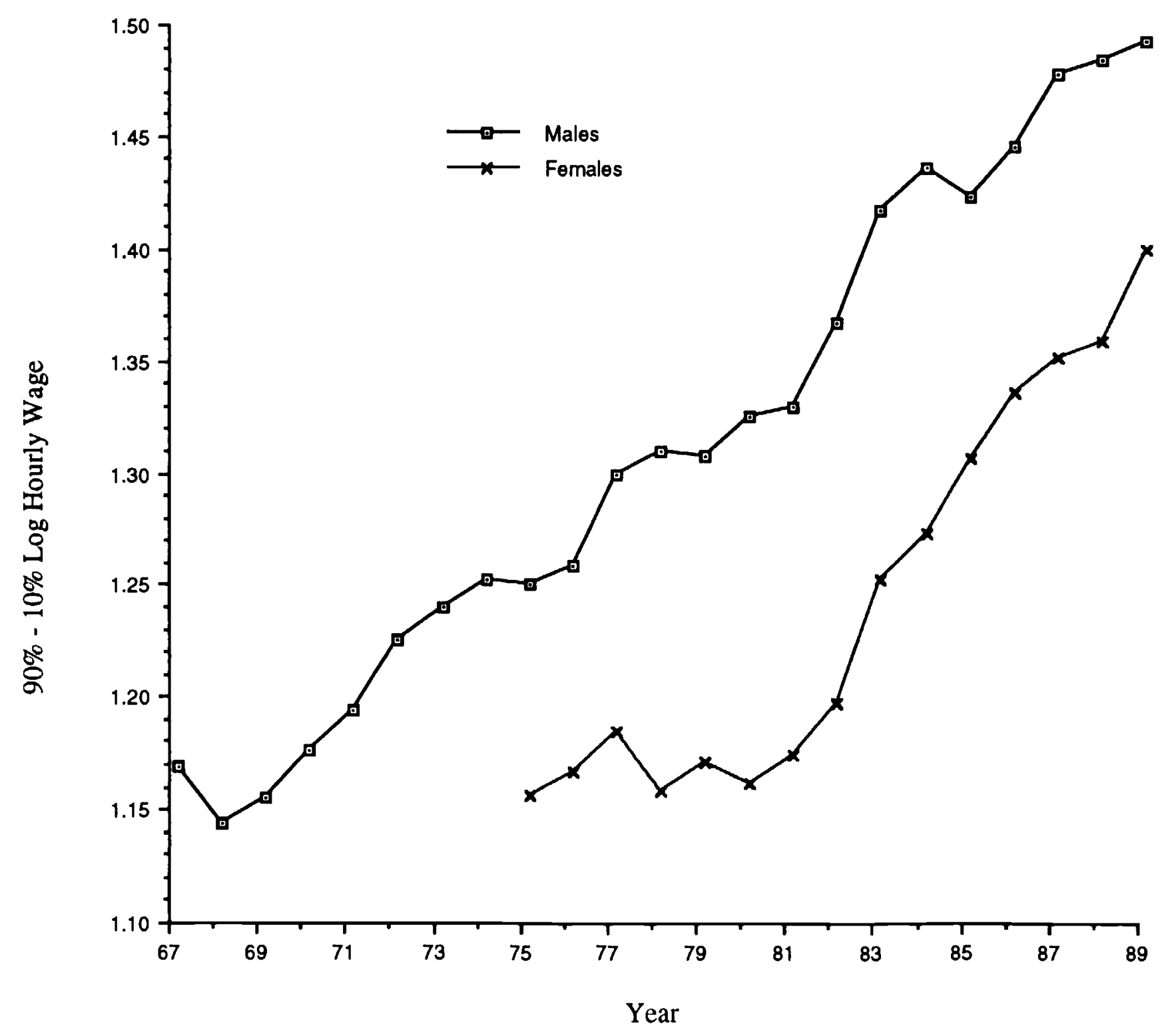

Source: Katz et al (1995) 
Figure 2b. Earnings inequality in Great Britain, 1970-1990

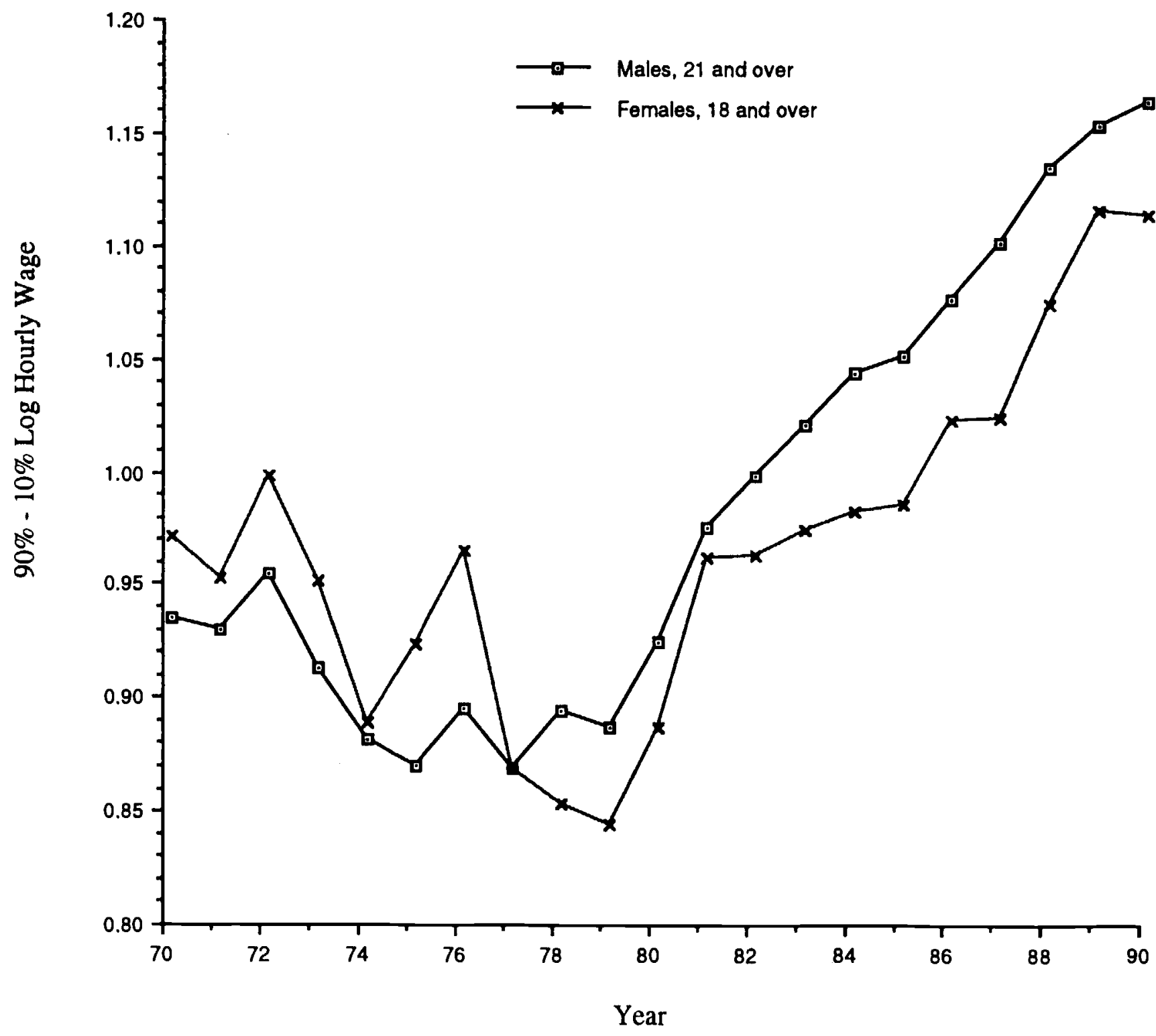

Source: Katz et al (1995) 
Figure 3a. United States, 18-65 Years Old

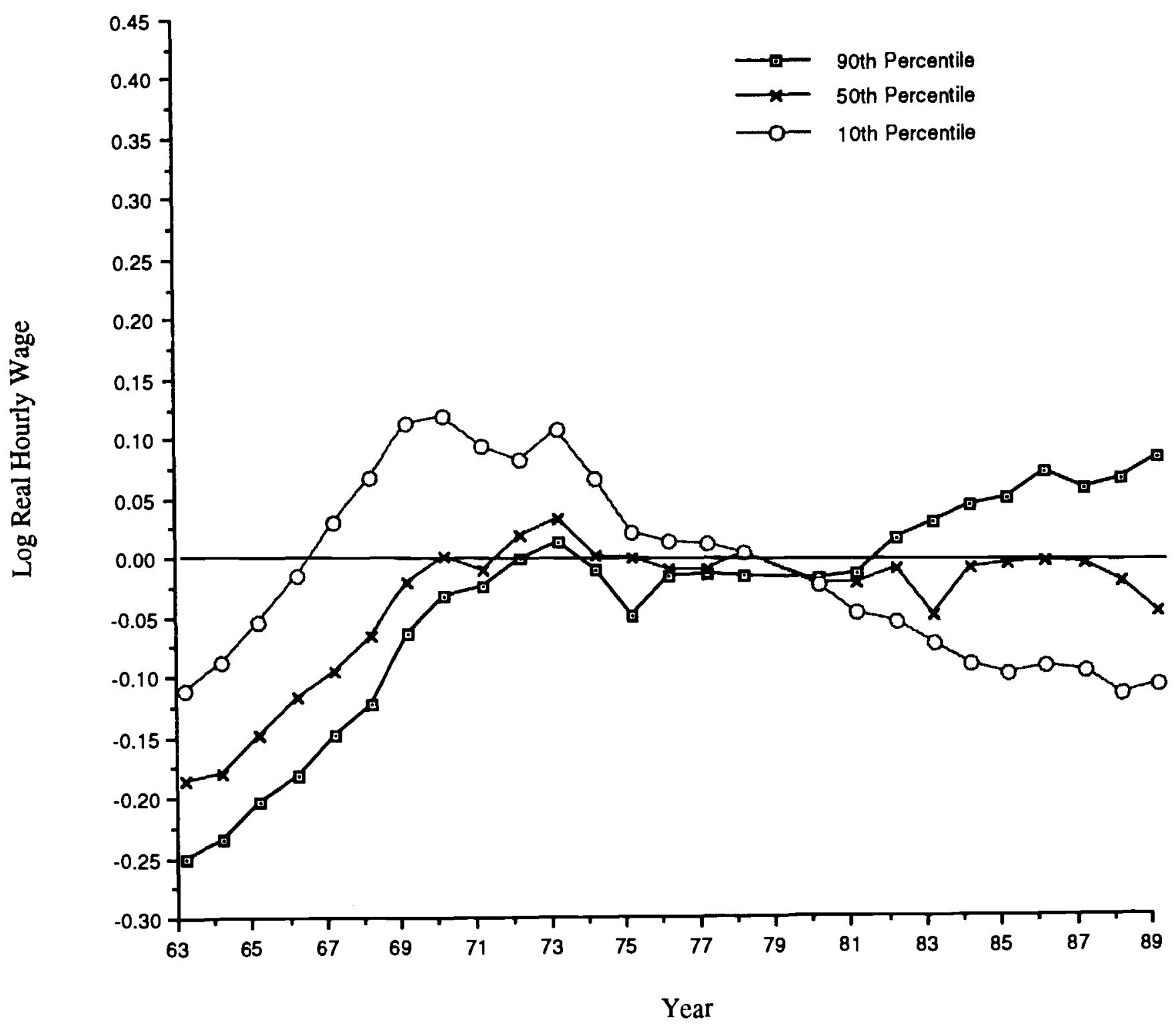

Source: Katz et al (1995) 
Figure 3b. Great Britain, 21 Years Old and Older

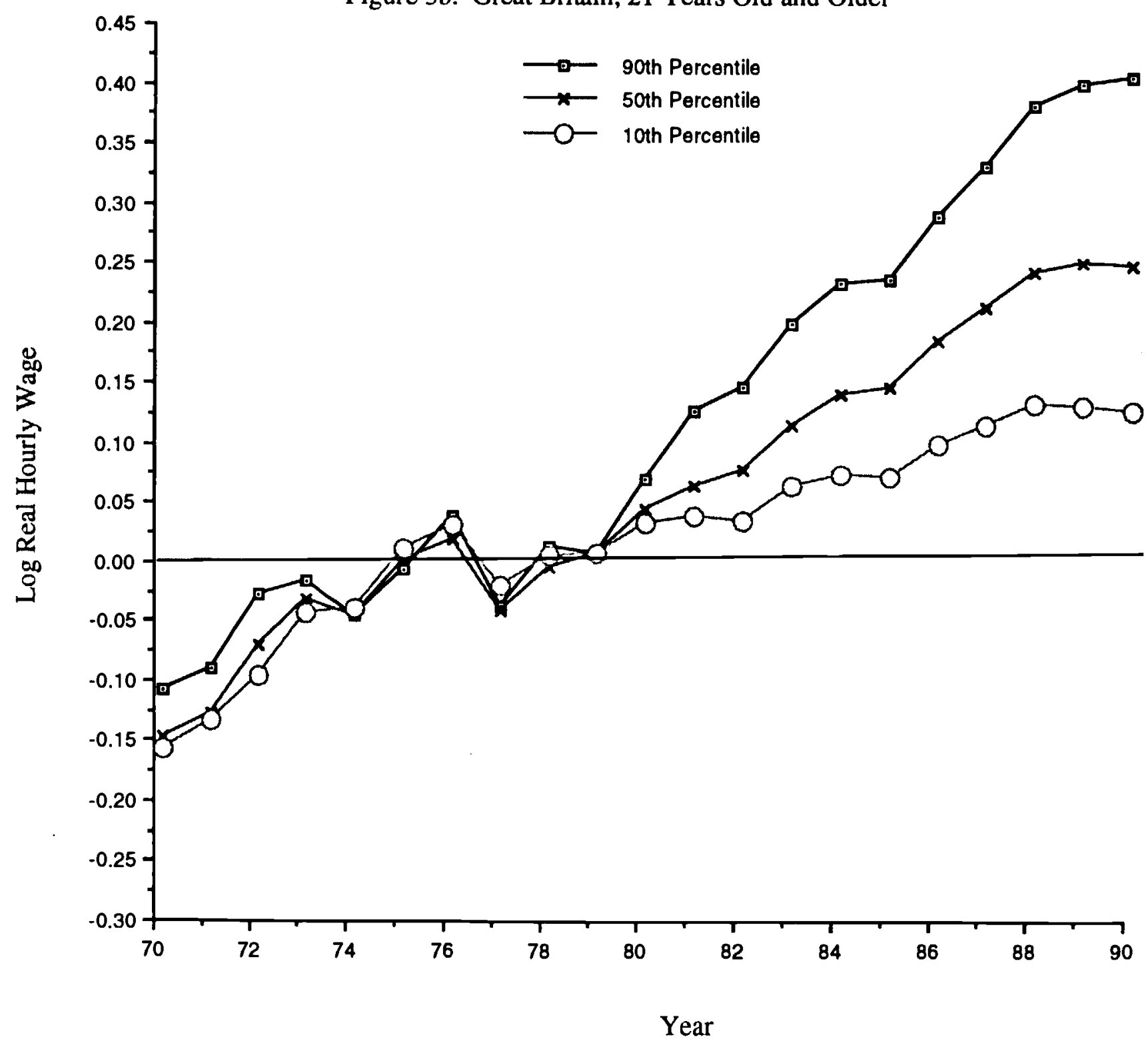

Source: Katz et al (1995) 
Figure 4. Union density rates, UK and USA, 1970-1993.

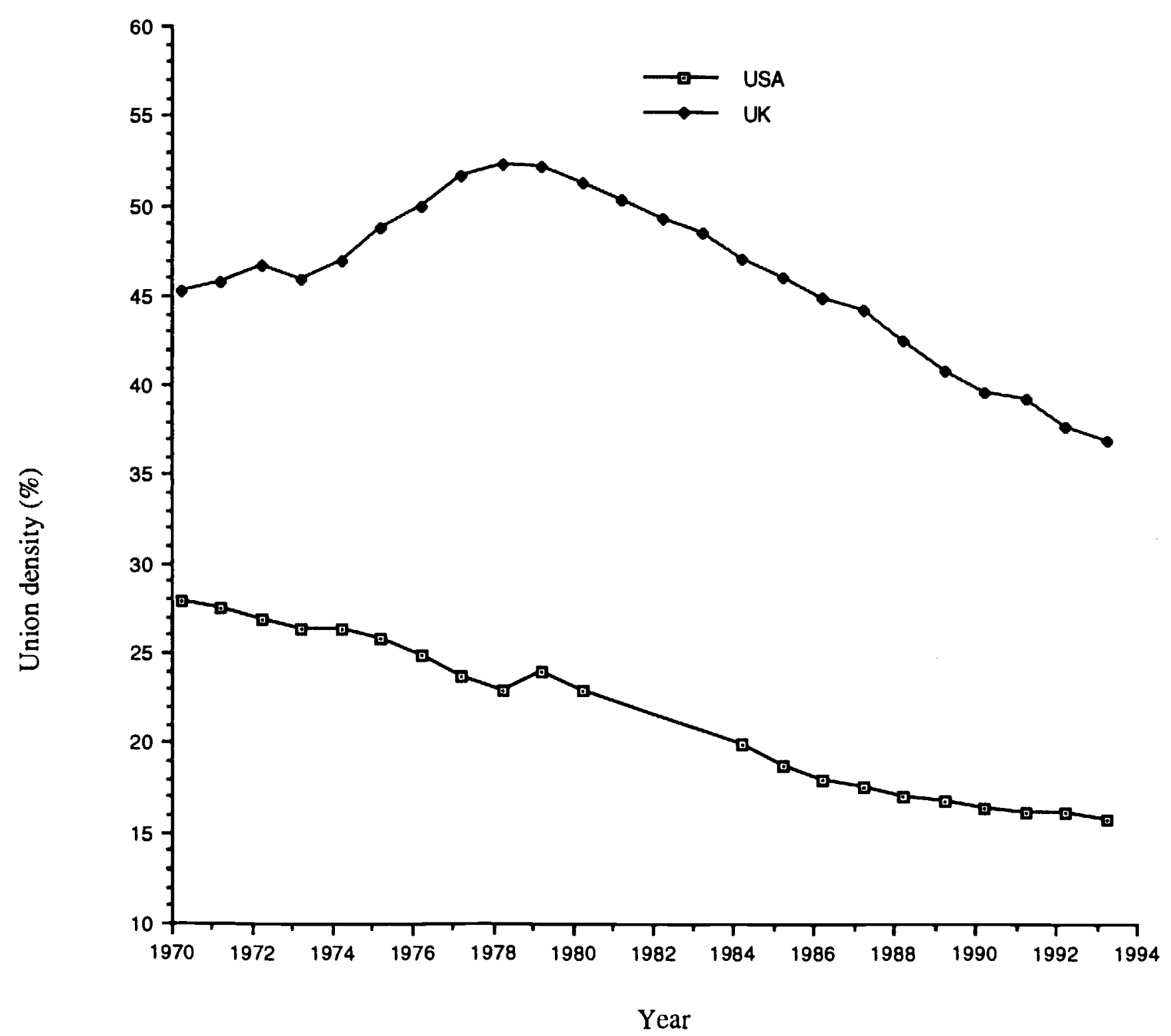

Source: Visser (1996) 
Figure 5. Union wage premia, USA, 1967-1995

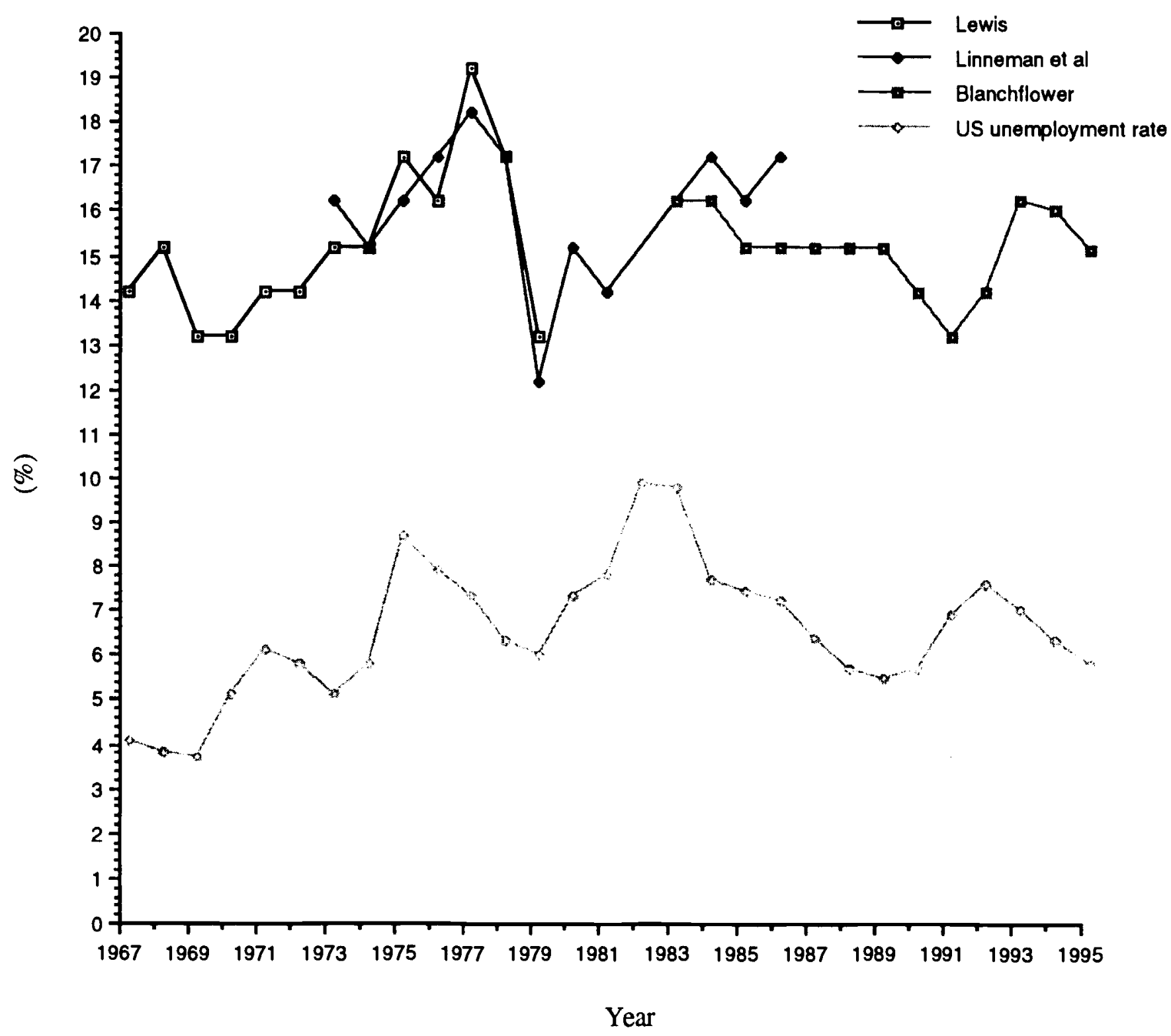


Figure 6. British union wage premia, 1983-1994.

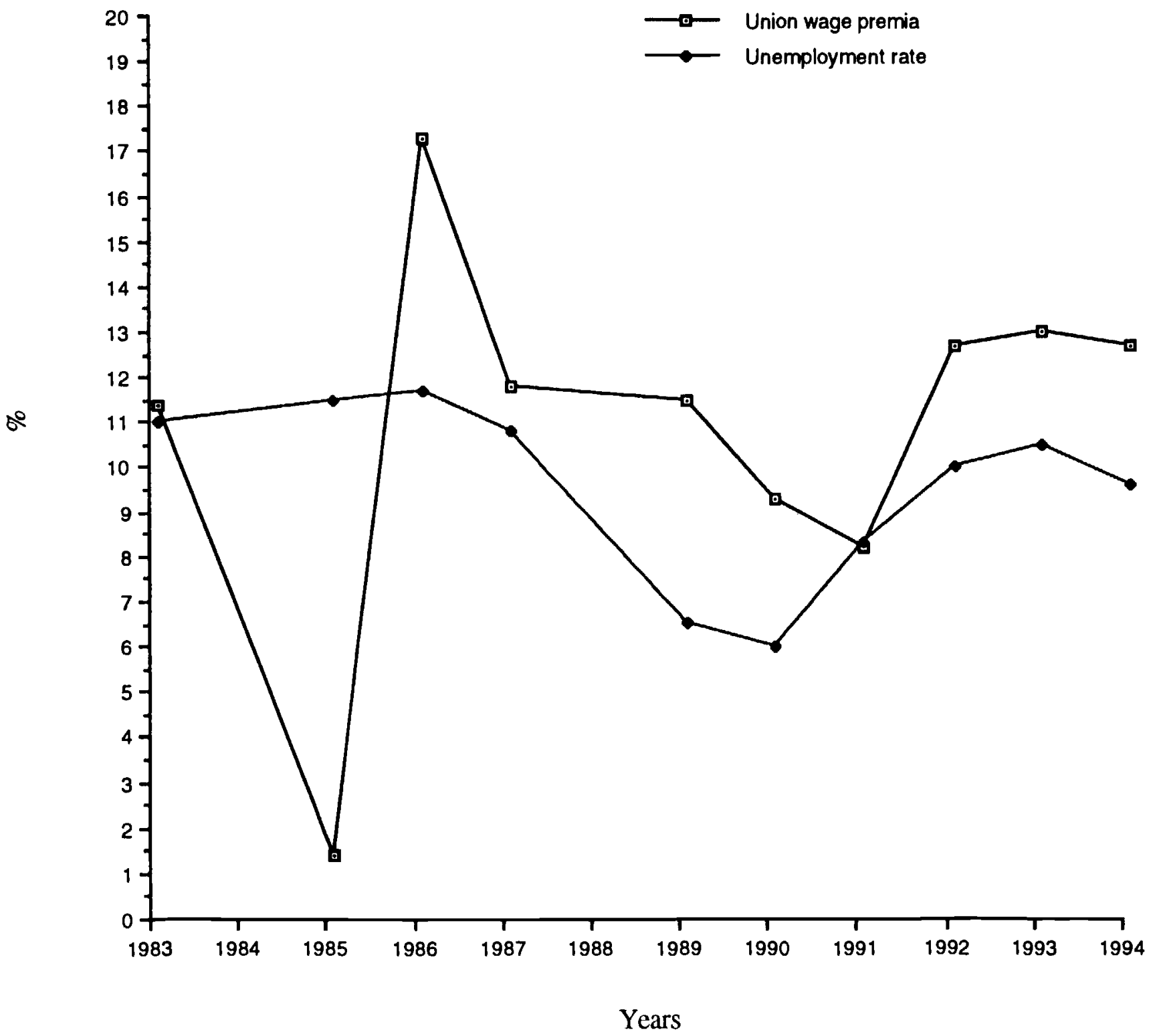

